\title{
KONTRIBUSI SEKTOR PERIKANAN DALAM PEREKONOMIAN KABUPATEN MALUKU TENGAH
}

\author{
Meitha M. Kaihatu \\ FMIPA - Universitas Terbuka \\ e-mail:mai@ecampus.ut.ac.id
}

\begin{abstract}
Maluku Tengah District have the potential fisheries resources. But the contribution of fishery against Gross Regional Domestic Product (GRDP) only of 6.20\%. In general, this research aims to identify and analyze the contribution of fisheries sector in the economy of the Maluku Tengah district, knowing the level of the base, and analyze the fishery economic typology. The methods used are secondary data analysis. Data analysis is an analysis of Shift Share analysis, Location Quotient (LQ), and analysis of the Klassen Typology. The calculation of the value of the contribution, the value of $L Q$, typology of economic sector of fisheries in Maluku Tengah district obtained the results that the contribution of fishery on the basis of prevailing prices and constant prices put the fishery on the order/rank fifth and sixth in the achieving of GRDP, the sector of fisheries in Maluku Tengah district is not a sector basis with patterns and economic structures that are growing but are at a condition relative's left behind. There are five sub-districts that became a priority and need to be developed/improved, among others: Banda, Tehoru, Salahutu, Leihitu, and Seram Utara.

Keywords: GRDP, contribution of the Fisheries Sector, Location Quotient $(L Q)$, Sector Bases, Shift Share, Klassen Typology
\end{abstract}

\begin{abstract}
ABSTRAK
Kabupaten Maluku Tengah memiliki potensi sumberdaya perikanan yang cukup besar. Namun sumbangan sektor perikanan terhadap Produk Domestik Regional Bruto (PDRB) hanya sebesar $6,20 \%$. Secara umum penelitian ini bertujuan untuk mengidentifikasi dan menganalisis kontribusi sektor perikanan dalam perekonomian wilayah Kabupaten Maluku Tengah, mengetahui tingkat basis, menganalisis tipologi ekonomi sektor perikanan.Metode yang digunakan adalah analisis data sekunder. Analisis data yang digunakan adalah analisis Shift Share, analisis Location Quotient $(\mathrm{LQ})$, dan Analisis Tipologi Klassen. Perhitungan nilai kontribusi, nilai LQ, tipologi ekonomi sektor perikanan di Kabupaten Maluku Tengah diperoleh hasil bahwa kontribusi sektor perikanan atas dasar harga berlaku dan harga konstan menempatkan sektor perikanan pada urutan/peringkat kelima dan keenam dalam pembentukan PDRB, sektor perikanan di Kabupaten Maluku Tengah bukan merupakan sektor basis dengan pola dan struktur ekonomi yang sedang bertumbuh namun berada pada kondisi relatif tertinggal. Terdapat lima kecamatan yang menjadi prioritas dan perlu dikembangkan/ditingkatkan antara lain: Banda, Tehoru, Salahutu, Leihitu, dan Seram Utara.
\end{abstract}

Kata kunci: PDRB, Kontribusi Sektor perikanan, Location Quotient (LQ), Sektor Basis,Shift Share, Tipologi Klassen 
Indikator tingkat keberhasilan pembangunan dan kesejahteraan masyarakat di suatu wilayah adalah ukuran Pendapatan Domestik Regional Bruto (PDRB) perkapita yang menggambarkan besarnya pendapatan rata-rata yang mungkin dicapai masyarakat (Sutiardi, 2001). Untuk itu, upaya peningkatan peran dan kontribusi yang nyata dari suatu sektor terhadap PDRB maupun PDRB perkapita perlu terus diupayakan. Upaya ini antara lain melalui optimalisasi pengembangan potensi sumberdaya alam yang dimiliki, serta diperlukan pemilihan sektor-sektor yang diprioritaskan, sehingga dapat menggunakan potensi ekonomi daerah secara optimal.terutama bagi daerah-daerah yang memiliki potensi sumberdaya yang belum dimanfaatkan secara baik.

Kabupaten Maluku Tengah merupakan salah satu Kabupaten di Provinsi Maluku yang memiliki potensi perikanan yang cukup besar. Kabupaten Maluku Tengah memiliki luas laut $264.311,43 \mathrm{~km}^{2}$ dan luas daratan 11.595,57 km², itu artinya wilayah Kabupaten Maluku Tengah didominasi oleh wilayah laut 95,8\% (BPS Maluku Tengah, 2010). Potensi sektor perikanan yang dimiliki oleh Kabupaten Maluku Tengah (Dinas Kelautan dan Perikanan Kabupaten Maluku, 2012) terbagi atas: potensi sumberdaya perikanan laut, potensi budidaya laut, dan potensi pengolahan hasil perikanan.

Potensi pertama berupa sumberdaya perikanan laut,wilayah Kabupaten Maluku Tengah memiliki potensi sumberdaya perikanan yang cukup unggul dan andal, terdiri atas panjang garis pantai $1.375,529 \mathrm{~km}$ dengan produksi perikanan laut sebesar 83.304 ton. Alat dan sarana penangkapan yang digunakan adalah pukat cincin, jaring insang hanyut, jaring insang lingkar, jaring insang tetap, bagan perahu, bagan tancap, serok/tenggo, jaring lainnya, rawai tetap, huhate, pancing tonda, pancing ulur, pancing tegak, pancing cumi, pancing lain, sero dan bubu dengan total alat penangkapan sebanyak 24.536 buah. Produksi perikanan sebagian besar dipasarkan dalam bentuk ikan segar. Pengembangan industri penangkapan ikan berpeluang meningkatkan investasi di Kabupaten Maluku Tengah yang diarahkan pada pengembangan kegiatan sektor perikanan yang bersifat ekonomis penting, baik untuk masyarakat maupun daerah.

Potensi kedua berupa budidaya laut seperti mutiara, rumput laut, teripang, keramba apung, kerang-kerangan seluas 3.028,4 ha dengan luas pemanfaatan sebesar 85,1 ha, potensi budidaya air payau seperti tambak udang dan bandeng, tambak kepiting seluas 15.998,3 ha dengan luas pemanfaatan sebesar $3.693,3$ ha potensi budidaya air tawar seluas 70,8 ha dengan luas pemanfaatan sebesar 15,2 ha, potensi terumbu karang seluas $6.745,4$ ha, potensi hutan mangrove seluas 7.057,4 ha, potensi padang lamun seluas 1.879,3 ha.

Potensi ketiga adalah pengolahan hasil perikanan, berupa usaha pengolahan hasil perikanan di Kabupaten Maluku Tengah pada umumnya dikerjakan secara tradisional maupun modern dan lokasi pengolahannya dilakukan di kecamatan-kecamatan dalam bentuk sentra produksi dan perusahaan perikanan. Jenis produk olahan hasil perikanannya terdiri dari ikan kering (ikan asin) dan ikan asar/asap.

Potensi sumberdaya sektor perikanan dan sumberdaya manusia yang cukup besar, mencapai 361.698 jiwa (BPS Maluku Tengah, 2010), sangat potensialuntuk dikembangkan sehingga dapat meningkatkan pertumbuhan ekonomi dan pendapatan perkapita daerah. Berdasarkan pada potensi yang ada, maka perlu diketahui mengenai peranan yang telah diberikan oleh sektor perikanan terhadap pembangunan wilayah Kabupaten Maluku Tengah.Untuk itu, perlu dilakukan penelitian tentang "Kontribusi Sektor Perikanan dalam Perekonomian Kabupaten Maluku Tengah"

Artikel ini menjabarkan penelitian yang telah dilakukan pada tahun 2012. Secara khusus penelitian ini bertujuan untuk: pertama, mengidentifikasi dan menganalisis kontribusi sektor perikanan dalam perekonomian wilayah Kabupaten Maluku Tengah; kedua, mengetahui basis 
ekonomi sektor perikanan dalam perekonomian wilayah Kabupaten Maluku Tengah; dan ketiga menganalisis pola dan struktur pertumbuhandi Kabupaten Maluku Tengah.

\section{METODE}

Penelitian ini menggunakan analisis data sekunder melalui penelusuran kepustakaan dengan mengambil kasus di Kabupaten Maluku Tengah, Provinsi Maluku.Data yang digunakan antara lain: Produk Domestik Regional Bruto (PDRB) Kabupaten Maluku Tengah dan data PDRB Provinsi Maluku periode 5 (lima) tahun, yaitu data tahun 2006 hingga tahun 2010. Data PDRB tersebut terdiri dari dua versi, yaitu nilai PDRB atas dasar harga berlaku dan nilai PDRB atas dasar harga konstan suatu tahun tertentu.

Sumber data yang digunakan dalam penelitian ini berasal dari instansi: BPS Provinsi Maluku, BPS Kabupaten Maluku Tengah, dan Dinas Kelautan dan Perikanan Kabupaten Maluku Tengah. Data sekunder dikumpulkan langsung dari instansi terkait baik ditingkat Kabupaten maupun Provinsi Maluku, maupun data penunjang lainnya yang relevan dengan topik atau bahasan penelitian. Terdapat 3 (tiga) metode analisis data yang digunakan dalam penelitian ini, yaitu: analisis kontribusi sektor perikanan, analisis sektor basis, dan analisispola dan struktur pertumbuhan.

Metode analisis data yang pertama, yaitu analisis kontribusi sektor perikanan, merupakan bagian dari analisis Shift share yang bertujuan untuk mengetahui besarnya kontribusi sektor perikanan terhadap PDRB. Jika perubahan nilai kontribusi bernilai positif maka sektor tersebut memiliki keunggulan kompetitif dan sebaliknya jika perubahan nilai kontribusi bernilai negatif maka sektor tersebut tidak memiliki keunggulan kompetitif.Metode analisis yang kedua, yaitu analisis sektor basis digunakan untuk mengetahui apakah sektor perikanan merupakan sektor basis atau sektor non-basis, dengan menggunakan pendekatan Location Quotient (LQ). Kriteria penilaian LQ yaitu: jika $L Q<1$, berarti sektor perikanan bukan merupakan kegiatan basis dalam wilayah Kabupaten Maluku Tengah; jika $L Q>1$, berarti sektor perikanan merupakan kegiatan basis dalam wilayah Kabupaten Maluku Tengah.

Metode analisis ketiga, yaitu analisis pola dan struktur pertumbuhan dilakukan dengan menggunakan Tipologi Klassen, yang pada dasarnya membagi daerah berdasarkan 2 (dua) indikator utama, yaitu pertumbuhan ekonomi daerah dan pendapatan perkapita daerah. Dengan menentukan rata-rata pertumbuhan ekonomi sebagai sumbu vertikal dan rata-rata perdapatan perkapita sebagai sumbu horisontal, daerah yang diamati dapat dibagi menjadi 4 klasifikasi yaitu: sektor maju dan tumbuh dengan pesat, sektor maju tapi tertekan, sektor potensial atau masih dapat berkembang, dan sektor relatif tertinggal.

\section{HASIL DAN PEMBAHASAN}

Penelitian tahap pertama menggunakan alat analisis kontribusi sektor perikanan, menghasilkan kontribusi sektor yang menunjukkan berapa besarnya sumbangan sektor yang bersangkutan terhadap PDRB (Produk Domestik Regional Bruto) secara keseluruhan. Kontribusi sektor yang dianalisis melalui pendekatan ini adalah kontribusi sektor perikanan terhadap PDRB Kabupaten Maluku Tengah. Kontribusi sektor perikanan atas dasar harga berlaku di Kabupaten Maluku Tengah (Tabel 1) selama 5 tahun (2006-2010)sektor perikanan di Kabupaten Maluku Tengah telah memberikan sumbangan pada pembentukan PDRB Kabupaten Maluku Tengah sebesar 6,20\%. 
Tabel 1. Kontribusi Sektor Perikanan Atas Dasar Harga Berlaku di Kabupaten Maluku Tengah

\begin{tabular}{ccccc}
\hline Tahun & $\begin{array}{c}\text { Nilai PDRB Sektor } \\
\text { Perikanan } \\
\text { (dalam juta rupiah) }\end{array}$ & $\begin{array}{c}\text { Nilai PDRB } \\
\text { Seluruh Sektor } \\
\text { (dalam juta rupiah) }\end{array}$ & $\begin{array}{c}\text { Kontribusi } \\
\text { Sektor } \\
\text { Perikanan } \\
(\%)\end{array}$ & $\begin{array}{c}\text { Perubahan Nilai } \\
\text { Kontribusi Sektor } \\
\text { Perikanan } \\
(\%)\end{array}$ \\
\hline 2006 & $46.413,73$ & $753.090,73$ & 6,16 & - \\
2007 & $52.628,53$ & $840.250,12$ & 6,26 & 0,10 \\
2008 & $59.786,78$ & $933.878,64$ & 6,40 & 0,14 \\
2009 & $65.078,97$ & $1.046 .800,60$ & 6,22 & $-0,19$ \\
2010 & $70.950,08$ & $1.186 .964,97$ & 5,98 & $-0,24$ \\
\hline Rata-Rata & $58.971,62$ & $952.196,94$ & 6,20 & $-0,05$ \\
\hline
\end{tabular}

Sumber: Data Sekunder setelah diolah, 2012

Perkembangan kontribusi sektor perikanan di Kabupaten Maluku Tengah bervariasi dan cenderung menurun hingga tahun 2010 (Gambar 1). Variasi ini dikarenakan dari tahun 2006 hingga 2008 terjadi peningkatan angka kontribusi sektor perikanan akibat besarnya perubahan nilai PDRB sektor perikanan atas dasar harga berlaku di Kabupaten Maluku Tengah. Persentase perubahan nilai PDRB pada dua tahun ini lebih besar dari persentase perubahan nilai PDRB seluruh sektor di Kabupaten Maluku Tengah, yang hanya sebesar 11,57\% pada tahun 2007 dan 11,14\% pada tahun 2008.
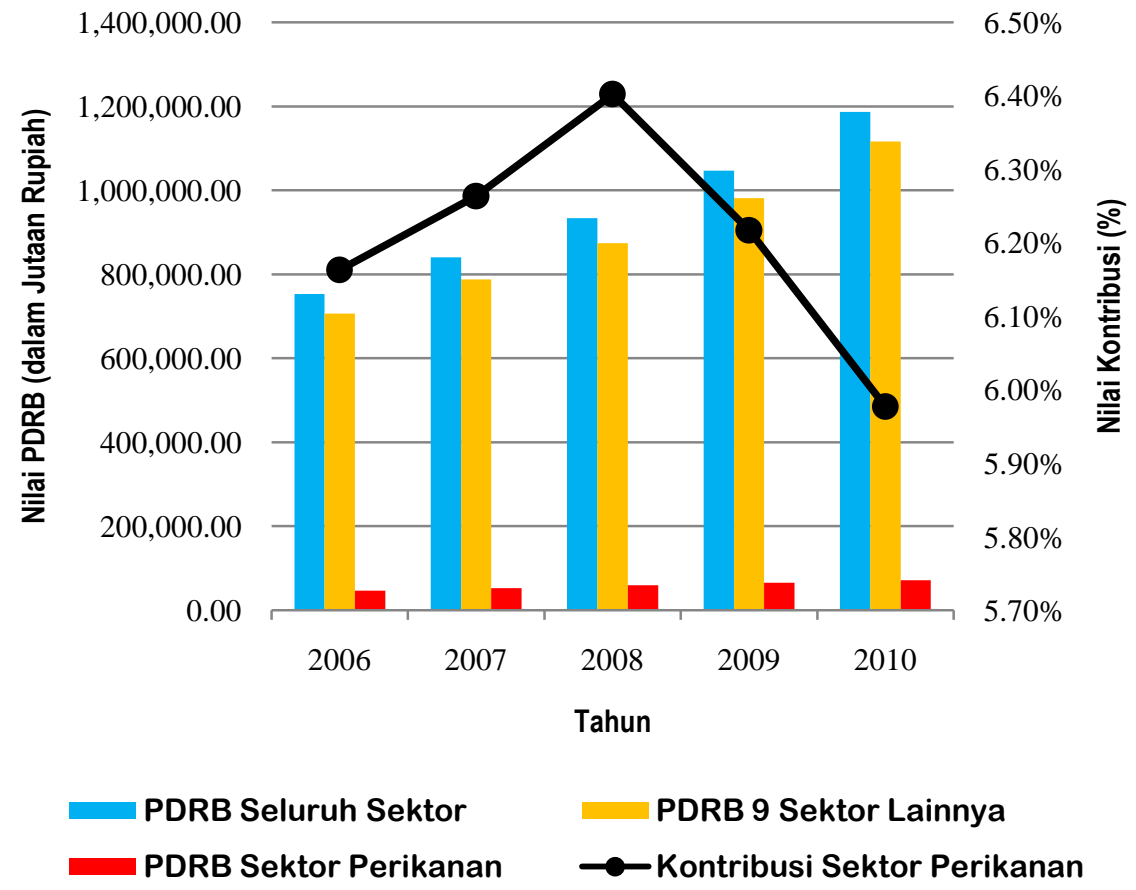

Gambar 1. Perkembangan PDRB dan kontribusi sektor perikanan atas dasar harga berlaku di Kabupaten Maluku Tengah 
Walaupun nilai PDRB sektor perikanan terus bertambah dari tahun 2008 hingga 2010, namun terjadi penurunan nilai kontribusi pada tahun 2009 hingga tahun 2010. Hal ini dikarenakan penurunan besarnya perubahan nilai PDRB yang terjadi pada tahun 2009 dan tahun 2010. Persentase perubahan nilai PDRB sektor perikanan pada dua tahun ini lebih kecil dari persentase perubahan nilai PDRB seluruh sektor di Kabupaten Maluku Tengah yang terus meningkat hingga 11,90\% pada tahun 2009 dan 13,39\% pada tahun 2010.

Dengan demikian, dalam hal sumbangannya terhadap pembentukan PDRB di Kabupaten Maluku Tengahdari tahun 2006 hingga tahun 2008, maka produksi dan harga komoditas perikanan yang terwakili dalam nilai PDRB sektor perikanan di Kabupaten Maluku Tengah menunjukkan perkembangan yang meningkat.Sebaliknya pada tahun 2009 dan tahun 2010 produksi dan harga komoditas perikanan menunjukkan penurunan. Penurunan kontribusi ini diakibatkan perkembangan produksi dan harga komoditas atau jasa sembilan sektor lain (selain sektor perikanan) yang meningkat pada tahun 2009 dan tahun 2010, dimana perubahan nilai PDRB sembilan sektor lainnya adalah masing-masing sebesar $12,31 \%$ dan $13,68 \%$. Hal ini menekan sumbangan sektor perikanan dalam PDRB atas dasar harga berlaku pada tahun 2010 yang berada pada urutan ke lima (5) dari sembilan sektor lainnya di Kabupaten Maluku Tengah.

Dengan standar atau patokan tingkat harga yang berlaku pada tahun 2000 , dikenal adanya PDRB atas dasar harga konstan, yakni harga produk didasarkan atas harga pada tahun tertentu (Tarigan, 2012). Kontribusi sektor perikanan terhadap PDRB Kabupaten Maluku Tengah atas dasar harga konstan (Tabel 2) selama 5 tahun menunjukkan sektor perikanan di Kabupaten Maluku Tengah telah memberikan sumbangan pada pembentukan PDRB Kabupaten Maluku Tengah sebesar $5,48 \%$.

Tabel 2. Kontribusi Sektor Perikanan Atas Dasar Harga Konstan Tahun 2000 di Kabupaten Maluku Tengah

\begin{tabular}{|c|c|c|c|c|}
\hline Tahun & $\begin{array}{l}\text { Nilai PDRB Sektor } \\
\text { Perikanan } \\
\text { (dalam juta rupiah) }\end{array}$ & $\begin{array}{l}\text { Nilai PDRB } \\
\text { Seluruh Sektor } \\
\text { (dalam juta } \\
\text { rupiah) }\end{array}$ & $\begin{array}{l}\text { Kontribusi } \\
\text { Sektor } \\
\text { Perikanan } \\
(\%)\end{array}$ & $\begin{array}{c}\text { Perubahan Nilai } \\
\text { Kontribusi Sektor } \\
\text { Perikanan } \\
(\%)\end{array}$ \\
\hline 2006 & $28.015,77$ & $508.158,19$ & 5,51 & - \\
\hline 2007 & $29.198,04$ & $534.169,12$ & 5,47 & $-0,05$ \\
\hline 2008 & $30.527,11$ & $561.764,23$ & 5,43 & $-0,03$ \\
\hline 2009 & $31.937,46$ & $592.946,33$ & 5,39 & $-0,05$ \\
\hline 2010 & $34.735,18$ & $621.692,54$ & 5,59 & 0,20 \\
\hline Rata-Rata & $30.882,71$ & $563.746,08$ & 5,48 & 0,02 \\
\hline
\end{tabular}

Perkembangan kontribusi sektor perikanan atas dasar harga konstan di Kabupaten Maluku Tengah cenderung menurun hingga tahun 2009, namun terjadi peningkatan yang signifikan pada tahun 2010 (Gambar 2). Penurunan angka kontribusi terjadi dari tahun 2006 hingga tahun 2009, penurunan ini diakibatkan oleh kecilnya perubahan nilai PDRB sektor perikanan atas dasar harga konstan. Di sisi lain perubahan nilai PDRB secara keseluruhan yang melibatkan 9 sektor lainnya lebih besar dari perubahan nilai PDRB sektor perikanan. Dengan demikian selama tahun 2006 hingga tahun 2009 perubahan nilai PDRB sektor perikanan lebih kecil dari perubahan nilai PDRB sembilan sektor lain. 
Berbeda dengan empat tahun sebelumnya, angka kontribusi sektor perikanan meningkat tajam pada tahun 2010 (Gambar 2). Peningkatan ini terjadi karena besarnya perubahan nilai sektor perikanan dibandingkan dengan perubahan nilai PDRB sembilan sektor lainnya yang hanya 4,63\%.

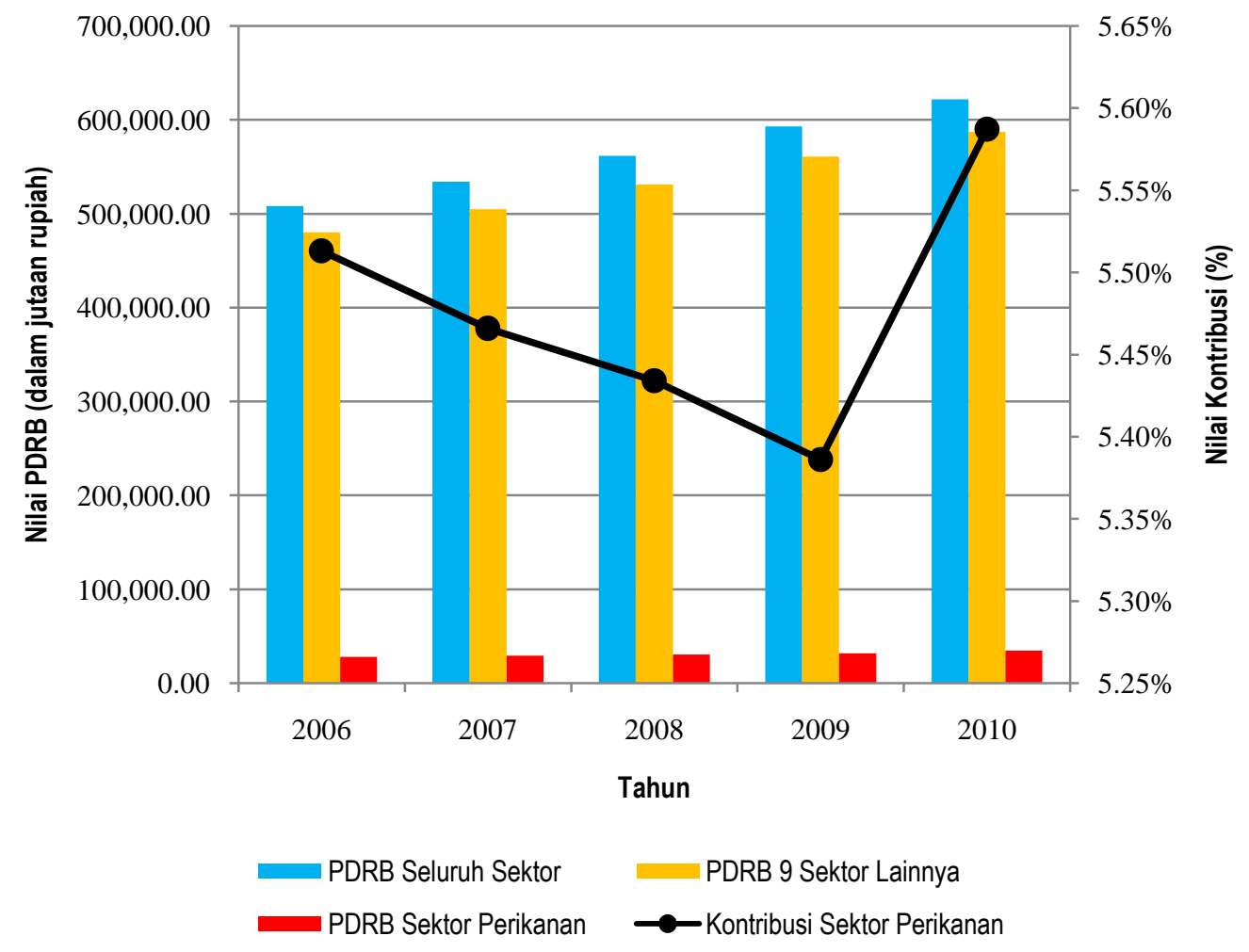

Gambar 2. Perkembangan PDRB dan kontribusi sektor perikanan atas dasar harga konstan di Kabupaten Maluku Tengah

Menurut Tarigan (2012) kenaikan pendapatan dalam nilai PDRB atas dasar harga konstan hanya disebabkan oleh meningkatnya jumlah fisik produksi, karena harga dianggap tetap (konstan). Peningkatan dan penurunan nilai PDRB sektor perikanan ataupun kontribusi sektor perikanan di Kabupaten Maluku Tengah atas dasar harga konstan menggambarkan peningkatan dan penurunan produksinya.

Secara keseluruhan, kontribusi sektor perikanan terhadap PDRB Kabupaten Maluku Tengah dari tahun 2006 hingga 2010, baik atas dasar harga berlaku maupun atas dasar harga konstan, menempatkan sektor perikanan pada urutan atau peringkat kelima dan keenam sebagai salah satu sektor penyumbang (share). Dengan demikian kebijakan untuk meningkatkan produksi dalam sektor perikanan yang meliputi sektor perikanan tangkap, sektor perikanan budidaya laut, sektor perairan umum, sektor budidaya jaring apung, sektor budidaya air tawar sawah, kolam dan keramba, serta sektor budidaya air payau perlu dilakukan oleh intansi terkait di Kabupaten Maluku Tengah.

Jika dilihat dari nilai kontribusi sektor perikanan, baik atas dasar harga berlaku ataupun harga konstan, per kecamatan di Kabupaten Maluku Tengah (Gambar 3), maka terdapat lima kecamatan yang memiliki nilai kontribusi terendah yakni Kecamatan Teluk Elpaputih, Kecamatan 
Teon Nila Serua, Kecamatan Saparua, Kecamatan Nusalaut, dan Kecamatan Pulau Haruku. Produksi sektor perikanan (kegiatan pada lapangan usaha perikanan) pada kecamatan ini harus menjadi prioritas dan perlu dikembangkan/ditingkatkan.

Kecamatan di Kabupaten Maluku Tengah yang memiliki nilai kontribusi tertinggi atas dasar harga konstan dari tahun 2006 hingga tahun 2010 adalah Kecamatan Salahutu, Kecamatan Banda, Kecamatan Tehoru, Kecamatan Leihitu, Kecamatan Seram Utara, Kecamatan Amahai, Kota Masohi, Kecamatan Leihitu Barat, dan Kecamatan Seram Utara Barat.
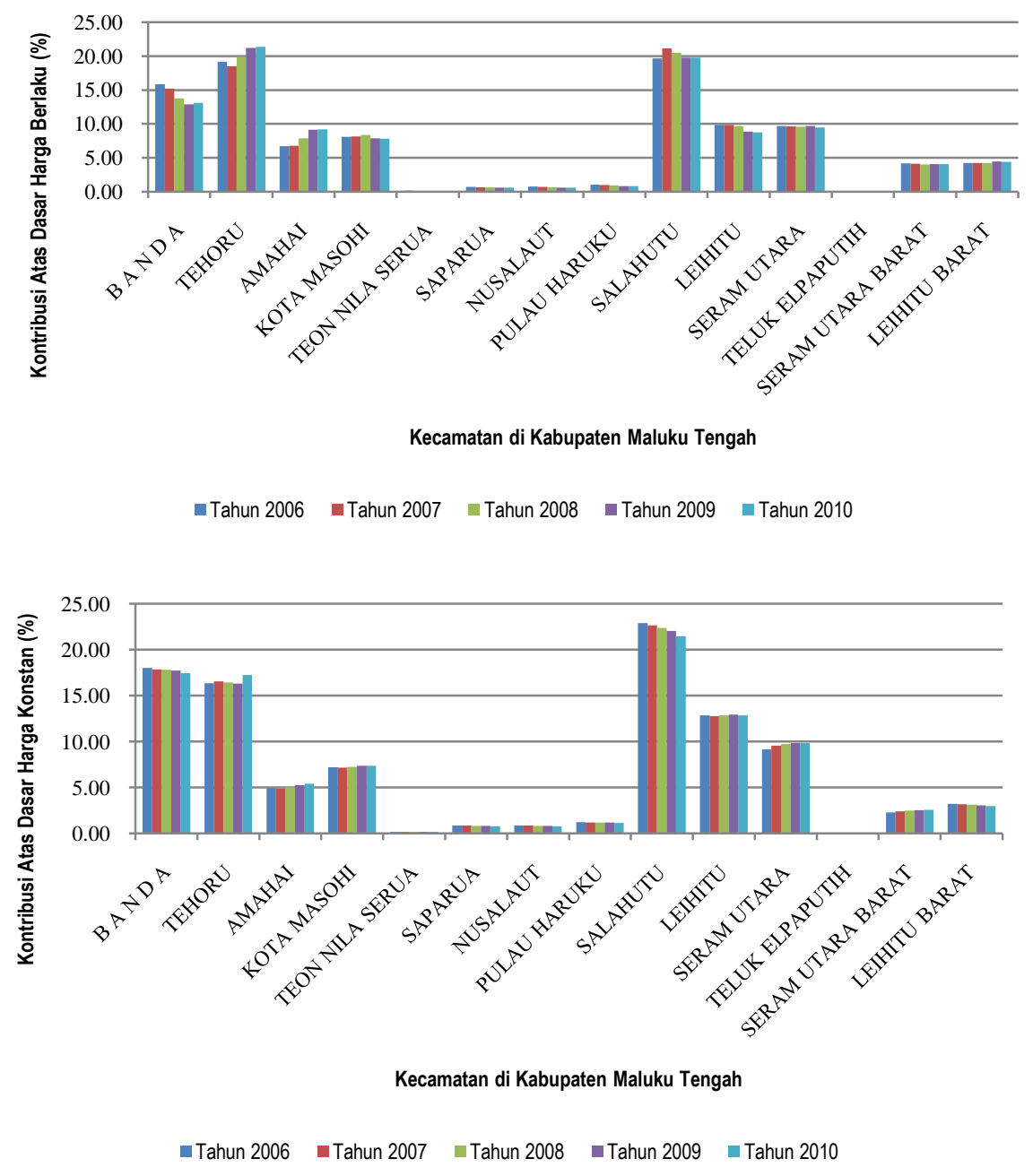

Gambar 3. Kontribusi Sektor Perikanan Per Kecamatan di Kabupaten Maluku Tengah

Penelitian tahap kedua menggunakan alat analisis Location Quotient (LQ) yang bertujuan untuk mengidentifikasi suatu sektor (lapangan usaha) yang ada pada suatu wilayah apakah termasuk ke dalam suatu sektor basis atau non-basis. Selain itu menurut Tarigan (2012) LQ juga merupakan perbandingan tentang besarnya peranan suatu sektor/industri di suatu daerah terhadap besarnya peranan sektor/industri tersebut secara nasional (wilayah induk/wilayah atasan). 
Tabel 3. Nilai LQ Sektor Perikanan Atas Dasar Harga Berlaku di Kabupaten Maluku Tengah

\begin{tabular}{|c|c|c|c|c|c|c|}
\hline Tahun & $\begin{array}{l}\text { Nilai PDRB } \\
\text { Sektor } \\
\text { Perikanan di } \\
\text { Kabupaten } \\
\text { Maluku Tengah } \\
\left(\mathrm{V}_{\mathrm{i}}\right) \\
\end{array}$ & $\begin{array}{c}\text { Nilai PDRB } \\
\text { Seluruh Sektor } \\
\text { di Kabupaten } \\
\text { Maluku Tengah } \\
\left(\mathrm{P}_{\mathrm{i}}\right)\end{array}$ & $\begin{array}{l}\text { Nilai PDRB } \\
\text { Sektor } \\
\text { Perikanan di } \\
\text { Provinsi } \\
\text { Maluku } \\
\left(V_{t}\right) \\
\end{array}$ & $\begin{array}{c}\text { Nilai PDRB } \\
\text { Seluruh Sektor di } \\
\text { Provinsi Maluku } \\
\left(P_{t}\right)\end{array}$ & $\begin{array}{l}\text { Nilai } \\
\text { LQ }\end{array}$ & $\begin{array}{c}\text { Perubahan } \\
\text { Nilai LQ }\end{array}$ \\
\hline 2006 & $46.413,73$ & $753.090,37$ & $842.345,92$ & $5.079 .836,95$ & 0,372 & \\
\hline 2007 & $52.628,53$ & $840.250,12$ & $938.031,20$ & $5.698 .799,37$ & 0,381 & 0,009 \\
\hline 2008 & $59.786,78$ & $933.878,64$ & $1.013 .551,81$ & $6.269 .709,52$ & 0,396 & 0,015 \\
\hline 2009 & $65.078,97$ & $1.046 .800,60$ & $1.100 .197,49$ & $7.069 .092,74$ & 0,399 & 0,003 \\
\hline 2010 & $70.950,08$ & $1.186 .964,97$ & $1.258 .930,43$ & $8.084 .807,43$ & 0,384 & $-0,016$ \\
\hline Rataan & $58.971,62$ & $1.030 .611,37$ & $952.196,94$ & $6.440 .449,20$ & 0,386 & 0,003 \\
\hline
\end{tabular}

Sumber. Data Sekunder setelah diolah, 2012

Keterangan: Nilai PDRB dalam jutaan rupiah

Nilai LQ sektor perikanan di Kabupaten Maluku Tengah atas dasar harga berlaku selama lima tahun (tahun 2006 hingga tahun 2010) berkisar antara 0,372 hingga 0,399 atau rata-ratanya selama lima tahun tersebut adalah 0,386 (Tabel 3). Nilai ini kurang dari $1(\mathrm{LQ}<1)$, dengan demikian sektor perikanan di Kabupaten Maluku Tengah merupakan sektor non-basis, artinya sektor perikanan di Kabupaten Maluku Tengah belum/tidak mampu memenuhi kebutuhan dalam kabupaten tersebut, atau peranan sektor perikanan di Kabupaten Maluku Tengah lebih kecil dari pada peranan sektor perikanan di tingkat provinsi (Provinsi Maluku).

Nilai LQ yang tidak berbeda (sama) juga ditunjukkan oleh sektor perikanan di Kabupaten Maluku Tengah atas dasar harga konstan selama lima tahun (Tabel 4). Nilai tersebut berkisar antara 0,370 hingga 0,373 atau rata-ratanya selama lima tahun berada pada nilai 0,370 . Nilai ini kurang dari $1(\mathrm{LQ}<1)$, dengan demikian sektor perikanan di Kabupaten Maluku Tengah merupakan sektor nonbasis.

Tabel 4. Nilai LQ Sektor Perikanan Atas Dasar Harga Konstan di Kabupaten Maluku Tengah

\begin{tabular}{|c|c|c|c|c|c|c|}
\hline Tahun & $\begin{array}{l}\text { Nilai PDRB } \\
\text { Sektor } \\
\text { Perikanan di } \\
\text { Kabupaten } \\
\text { Maluku Tengah } \\
\left(\mathrm{V}_{\mathrm{i}}\right) \\
\end{array}$ & $\begin{array}{c}\text { Nilai PDRB } \\
\text { Seluruh Sektor } \\
\text { di Kabupaten } \\
\text { Maluku Tengah } \\
\left(\mathrm{P}_{\mathrm{i}}\right)\end{array}$ & $\begin{array}{c}\text { Nilai PDRB } \\
\text { Sektor } \\
\text { Perikanan di } \\
\text { Provinsi Maluku } \\
\qquad\left(\mathrm{V}_{\mathrm{t}}\right)\end{array}$ & $\begin{array}{c}\text { Nilai PDRB } \\
\text { Seluruh Sektor di } \\
\text { Provinsi Maluku } \\
\quad\left(\mathrm{P}_{\mathrm{t}}\right)\end{array}$ & $\begin{array}{l}\text { Nilai } \\
\text { LQ }\end{array}$ & $\begin{array}{c}\text { Perubahan } \\
\text { Nilai LQ }\end{array}$ \\
\hline 2006 & $28.015,77$ & $508.158,19$ & $508.509,46$ & $3.440 .114,10$ & 0,373 & \\
\hline 2007 & $29.198,04$ & $53.169,12$ & $533.548,26$ & $3.633 .475,13$ & 0,372 & $-0,001$ \\
\hline 2008 & $30.527,11$ & $561.764,23$ & $555.797,22$ & $3.787 .103,94$ & 0,370 & $-0,002$ \\
\hline 2009 & $31.937,46$ & $592.946,33$ & $583.689,67$ & $3.992 .788,03$ & 0,368 & $-0,002$ \\
\hline 2010 & $34.735,18$ & $621.692,54$ & $646.404,45$ & $4.251 .356,30$ & 0,367 & $-0,001$ \\
\hline Rataan & $30.882,71$ & $565.589,81$ & $563.746,08$ & $3.820 .967,50$ & 0,370 & $-0,001$ \\
\hline
\end{tabular}

Sumber: Data Sekunder setelah diolah, 2012

Keterangan: Nilai PDRB dalam jutaan rupiah 
Perkembangan nilai LQ sektor perikanan di Kabupaten Maluku Tengah atas dasar harga berlaku dan atas dasar harga konstan selama lima tahun (Gambar 4) menunjukkan bahwa sektor perikanan di Kabupaten Maluku Tengah tumbuh lebih lambat dari perkembangan sektor perikanan di Provinsi Maluku.

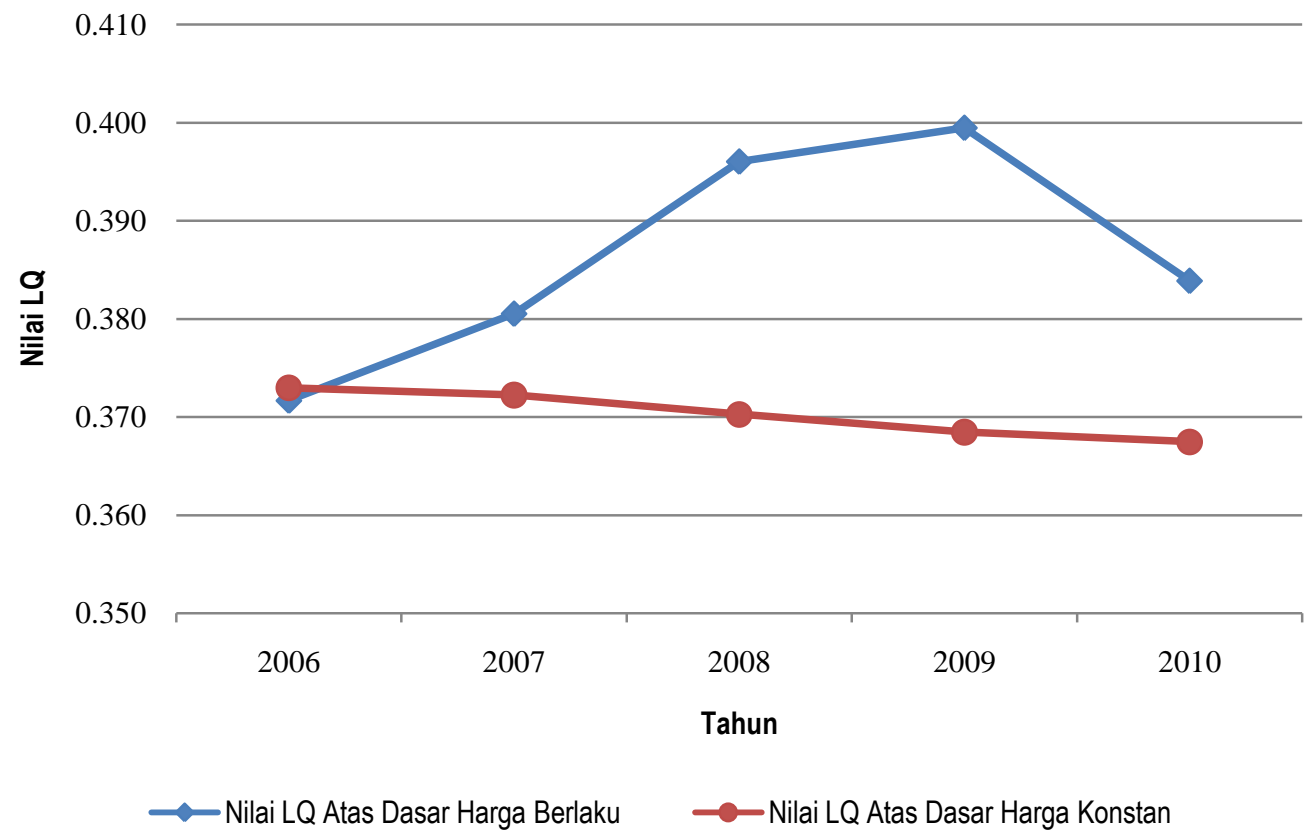

Gambar 4. Perkembangan Nilai LQ sektor perikanan di Kabupaten Maluku Tengah

Terkait dengan teori basis ekonomi (economic base theory) maka laju pertumbuhan ekonomi di Kabupaten Maluku Tengah ditentukan oleh besarnya peningkatan ekspor. Dari produksi 29 jenis komoditas hasil perikanan di Kabupaten Maluku Tengah selama tahun 2006 hingga tahun 2010, hanya empat jenis komoditas yang diekspor, yakni ikan tuna (Thunus albacores), ikan cakalang (Katsuwonus pelamis), ikan layang (Decapterus ruselli), dan udang windu (Peneaus monodon). Realisasi ekspor keempat jenis komoditas hasil perikanan tersebut (Gambar 5) pada tahun 2006 hingga tahun 2010 menunjukkan penurunan, baik produksi maupun nilai produksinya. Pada tahun ini hanya 3 jenis komoditas yang diekspor, yakni ikan tuna, ikan cakalang dan udang windu (Dinas Kelautan dan Perikanan Kabupaten Maluku Tengah, 2010).

Penurunan ekspor hasil perikanan di Kabupaten Maluku Tengah ini berhubungan dengan perkembangan nilai LQ sektor perikanan di Kabupaten Maluku Tengah. Dengan demikian peningkatan produksi untuk memenuhi permintaan pasar ekspor dan pengembangan strategi pemasaran terhadap 4 jenis komoditas yang diekspor harus dicermati secara serius dan ditindaklanjuti oleh pemerintah Kabupaten Maluku Tengah, khususnya Dinas Kelautan dan Perikanan Kabupaten Maluku Tengah. Menurut Tarigan (2012) perlu didorong pertumbuhan dari sektor/lapangan usaha yang hasil produksinya dapat dijual ke luar daerah sehingga mendatangkan pendapatan dari luar daerah. Bantuan penyediaan lapangan kerja dan bantuan modal harus 
diarahkan ke lapangan usaha yang memproduksi keempat jenis komoditas hasil perikanan yang diekspor seperti usaha hand line, pole and line, dan purse seine.

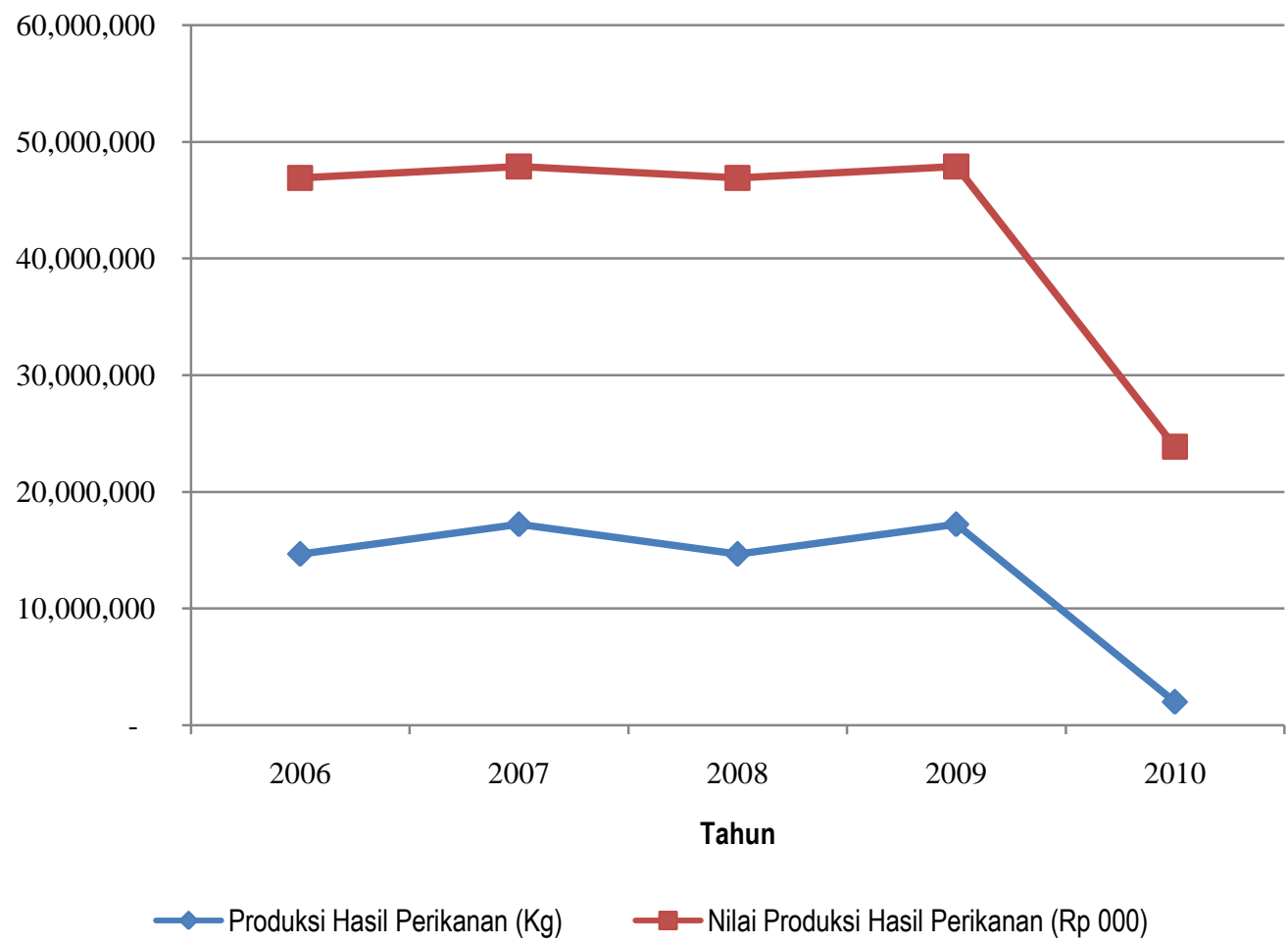

Gambar 5. realisasi ekspor hasil perikanan Kabupaten Maluku Tengah Tahun 2006-2010

Walaupun di tingkat kabupaten/kota di Provinsi Maluku sektor perikanan di Kabupaten Maluku Tengah bukan merupakan sektor basis, namun terdapattujuh kecamatan yang merupakan basis sektor perikanan di Kabupaten Maluku Tengah yakni, Kecamatan Banda, Kecamatan Tehoru, Kecamatan Salahutu, Kecamatan Leihitu, Kecamatan Seram Utara, Kecamatan Seram Utara Barat, dan Kecamatan Leihitu Barat (Gambar 6). Kecamatan-kecamatan ini memiliki nilai LQ lebih dari 1 ( $L Q>1$ ) selama lima tahun (dari tahun 2006 hingga tahun 2010) yang dianalisis melalui nilai PDRB atas dasar harga berlaku maupun atas dasar harga konstan. Dengan demikian pemasaran produk hasil perikanan pada tujuh kecamatan ini telah mendatangkan pendapatan dari daerah lain atau jangkauan pemasarannya telah mencakup wilayah di luar kecamatan-kecamatan tersebut. 


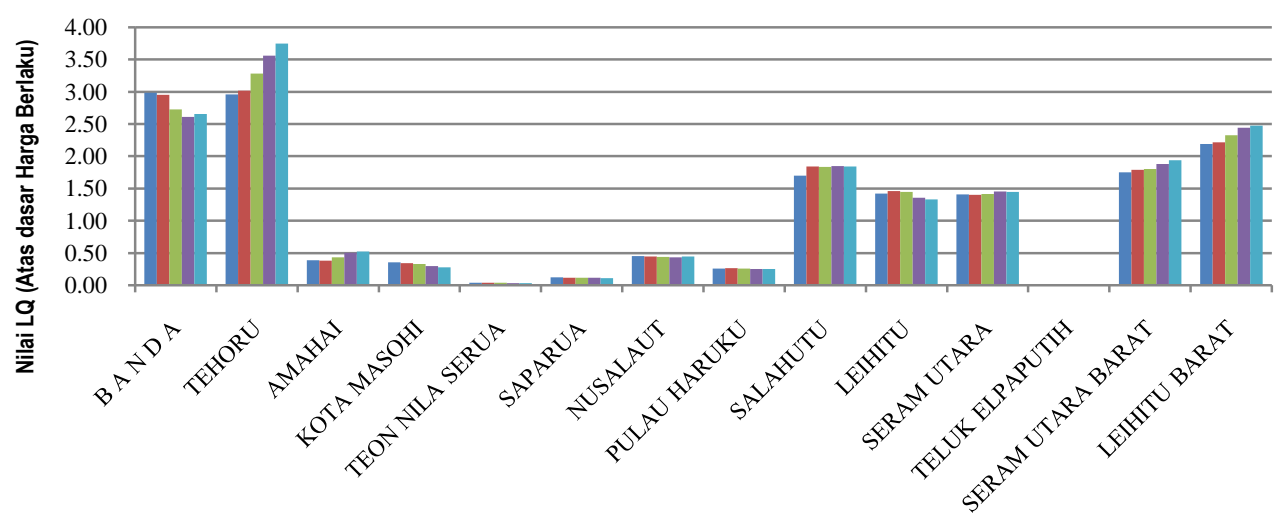

Kecamatan di Kabupaten Maluku Tengah

- Tahun 2006 - Tahun 2007 - Tahun 2008 - Tahun 2009 - Tahun 2010

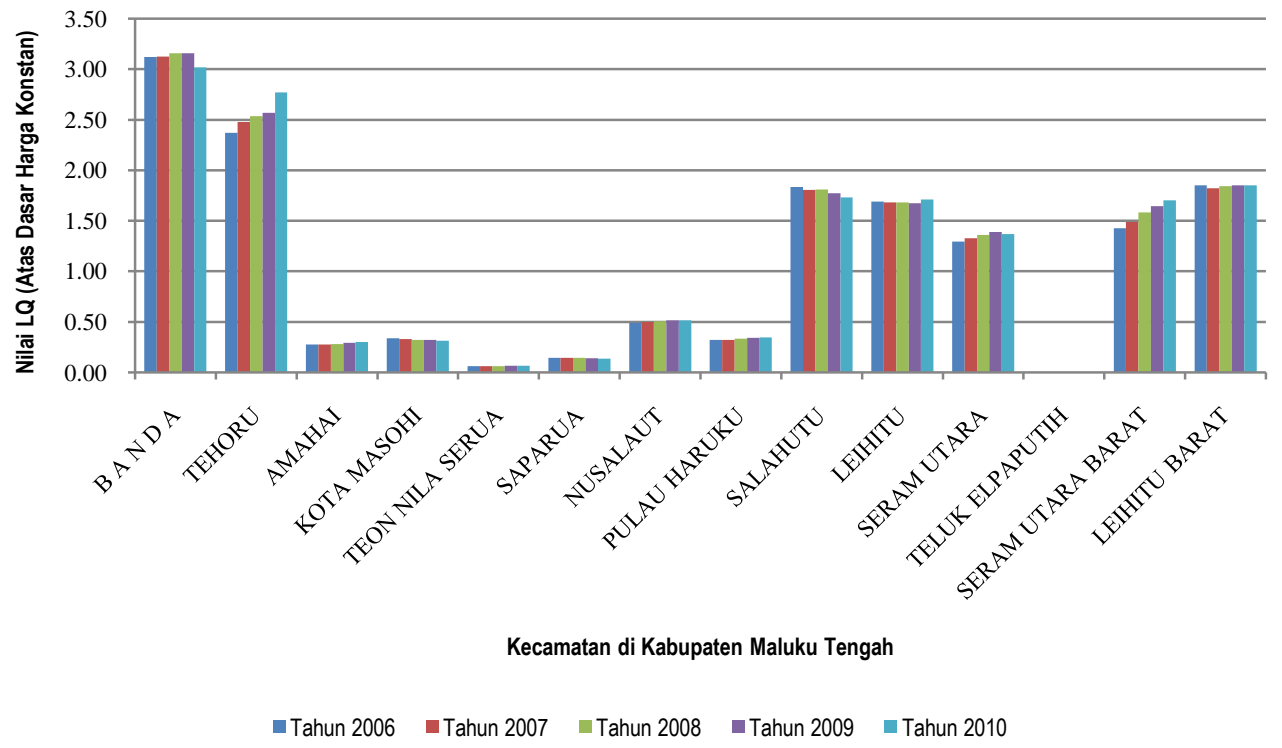

Gambar 6. Nilai LQ Sektor Perikanan Per Kecamatan di Kabupaten Maluku Tengah

Tahap ketiga penelitian ini adalah tingkat pertumbuhan sektor perikanan di Kabupaten Maluku Tengah serta kesenjangannya,yang dilakukan melalui analisis tipologi Klassen. Analisis tipologi Klassen dibagi menjadi empat klasifikasi (kuadran) yang memiliki karakterberbeda-beda. Berdasarkan data PDRB sektor perikanan di Kabupaten Maluku Tengah dan PDRB sektor perikanan di Provinsi Maluku, serta masing-masing jumlah penduduk di Kabupaten Maluku Tengah dan Provinsi Maluku diperoleh hasil analisis tingkat pertumbuhan sektor perikanan dan pendapatan perkapita sektor perikanan di Kabupaten Maluku Tengah dan Provinsi Maluku pada Tabel 5 dan Tabel 6 . 
Tabel 5. Tingkat Pertumbuhan dan Pendapatan Perkapita Sektor Perikanan Atas Dasar Harga Berlaku di Kabupaten Maluku Tengah dan Provinsi Maluku

\begin{tabular}{|c|c|c|c|c|c|c|}
\hline Tahun & $\begin{array}{c}\text { Tingkat } \\
\text { Pertumbuhan } \\
\text { Nilai PDRB } \\
\text { Sektor } \\
\text { Perikanan } \\
\text { Kabupaten } \\
\text { Maluku } \\
\text { Tengah } \\
(\%)\end{array}$ & $\begin{array}{l}\text { Pendapatan } \\
\text { Perkapita } \\
\text { Sektor } \\
\text { Perikanan di } \\
\text { Kabupaten } \\
\text { Maluku Tengah } \\
\text { (Rp) }\end{array}$ & $\begin{array}{c}\text { Tingkat } \\
\text { Pertumbuhan } \\
\text { Nilai PDRB } \\
\text { Sektor } \\
\text { Perikanan } \\
\text { Provinsi } \\
\text { Maluku } \\
(\%)\end{array}$ & $\begin{array}{l}\text { Pendapatan } \\
\text { Perkapita } \\
\text { Sektor } \\
\text { Perikanan di } \\
\text { Provinsi } \\
\text { Maluku (Rp) }\end{array}$ & $\begin{array}{l}\text { Perbedaan } \\
\text { Tingkat } \\
\text { Pertumbuhan } \\
\text { Nilai PDRB } \\
\text { Sektor } \\
\text { Perikanan } \\
(\%)\end{array}$ & $\begin{array}{c}\text { Perbedaan } \\
\text { Pendapatan } \\
\text { Perkapita } \\
\text { Sektor } \\
\text { Perikanan } \\
\text { (Rp) }\end{array}$ \\
\hline 2006 & - & $101.999,45$ & - & $549.294,18$ & - & $-447.294,72$ \\
\hline 2007 & 13,39 & $115.657,19$ & 11,36 & $611.690,60$ & 2,03 & $-496.033,41$ \\
\hline 2008 & 13,60 & $131.388,25$ & 8,05 & $660.937,62$ & 5,55 & $-529.549,37$ \\
\hline 2009 & 8,85 & $143.018,44$ & 8,55 & $717.439,31$ & 0,30 & $-574.420,86$ \\
\hline 2010 & 9,02 & $155.920,88$ & 14,43 & $820.949,14$ & $-5,41$ & $-665.028,26$ \\
\hline Rataan & 11,22 & $129.596,84$ & 10,60 & $672.062,17$ & 2,48 & $-542.465,33$ \\
\hline
\end{tabular}

Tabel 5 menunjukkan tingkat pertumbuhan dan pendapatan perkapita sektor perikanan di Kabupaten Maluku Tengah dan Provinsi Maluku atas dasar harga berlaku. Pertumbuhan sektor perikanan di Kabupaten Maluku Tengah berkisar antara 8,85\% hingga 13,60\% selama lima tahun atau rata-rata tiap tahun bertumbuh $11,22 \%$, sedangkan tingkat pertumbuhan sektor perikanan Provinsi Maluku berkisar antara $8,05 \%$ hingga $14,43 \%$ selama lima tahun atau rata-rata tiap tahun bertumbuh $10,60 \%$. Perbedaan tingkat pertumbuhan sektor perikanan di kedua daerah tersebut menunjukkan bahwa, tingkat pertumbuhan sektor perikanan di Provinsi Maluku selama kurun waktu lima tahun, hal ini terlihat dari nilai rata-rata perbedaan tingkat pertumbuhan sektor perikanan di kedua daerah tersebut sebesar 2,48\% (angka positif).

Tabel 6. Tingkat Pertumbuhan dan Pendapatan Perkapita Sektor Perikanan Atas Dasar Harga Konstan di Kabupaten Maluku Tengah dan Provinsi Maluku

\begin{tabular}{|c|c|c|c|c|c|c|}
\hline Tahun & $\begin{array}{c}\text { Tingkat } \\
\text { Pertumbuhan } \\
\text { Nilai PDRB } \\
\text { Sektor } \\
\text { Perikanan } \\
\text { Kabupaten } \\
\text { Maluku } \\
\text { Tengah } \\
(\%) \\
\end{array}$ & $\begin{array}{l}\text { Pendapatan } \\
\text { Perkapita } \\
\text { Sektor } \\
\text { Perikanan di } \\
\text { Kabuaten } \\
\text { Maluku } \\
\text { Tengah } \\
\text { (Rp) }\end{array}$ & $\begin{array}{c}\text { Tingkat } \\
\text { Pertumbuhan } \\
\text { Nilai PDRB } \\
\text { Sektor } \\
\text { Perikanan } \\
\text { Provinsi } \\
\text { Maluku } \\
(\%)\end{array}$ & $\begin{array}{l}\text { Pendapatan } \\
\text { Perkapita } \\
\text { Sektor } \\
\text { Perikanan di } \\
\text { Provinsi } \\
\text { Maluku (Rp) }\end{array}$ & $\begin{array}{c}\text { Perbedaan } \\
\text { Tingkat } \\
\text { Pertumbuhan } \\
\text { Nilai PDRB } \\
(\%)\end{array}$ & $\begin{array}{c}\text { Perbedaan } \\
\text { Pendapatan } \\
\text { Perkapita } \\
\text { (Rp) }\end{array}$ \\
\hline 2006 & - & $61.567,84$ & - & $331.599,26$ & - & $-270.031,41$ \\
\hline 2007 & 4,22 & $64.166,02$ & 4,92 & $347.927,08$ & $-0,70$ & $-283.761,06$ \\
\hline 2008 & 4,55 & $67.086,80$ & 4,17 & $362.435,63$ & 0,38 & $-295.348,83$ \\
\hline 2009 & 4,62 & $70.186,20$ & 5,02 & $380.624,31$ & $-0,40$ & $-310.438,11$ \\
\hline 2010 & 8,76 & $76.334,51$ & 10,74 & $421.520,65$ & $-1,98$ & $-345.186,14$ \\
\hline Rataan & 5,54 & $67.868,28$ & 6,21 & $368.821,39$ & $-0,68$ & $-300.953,11$ \\
\hline
\end{tabular}


Tabel 6 menunjukkan tingkat pertumbuhan dan pendapatan perkapita sektor perikanan di Kabupaten Maluku Tengah dan Provinsi Maluku atas dasar harga konstan tahun 2000. Pertumbuhan sektor perikanan di Kabupaten Maluku Tengah berkisar antara 4,22\% hingga 8,76\% atau rata-rata pertahun selama lima tahun sebesar $5,54 \%$. Pertumbuhan ini meningkat tiap tahunnya dari tahun 2006 hingga tahun 2010. Sedangkan tingkat pertumbuhan sektor perikanan di Provinsi Maluku berkisar antara $4,17 \%$ hingga $10,74 \%$ atau rata-rata selama lima tahun sebesar $6,21 \%$. Berdasarkan data yang ada terlihat bahwa perbedaan pendapatan perkapita sektor perikanan di Kabupaten Maluku Tengah dan di Provinsi Maluku terlihat dengan jelas, pendapatan perkapita sektor perikanan di Provinsi Maluku lebih besar dari pendapatan perkapita sektor perikanan di Kabupaten Maluku Tengah.

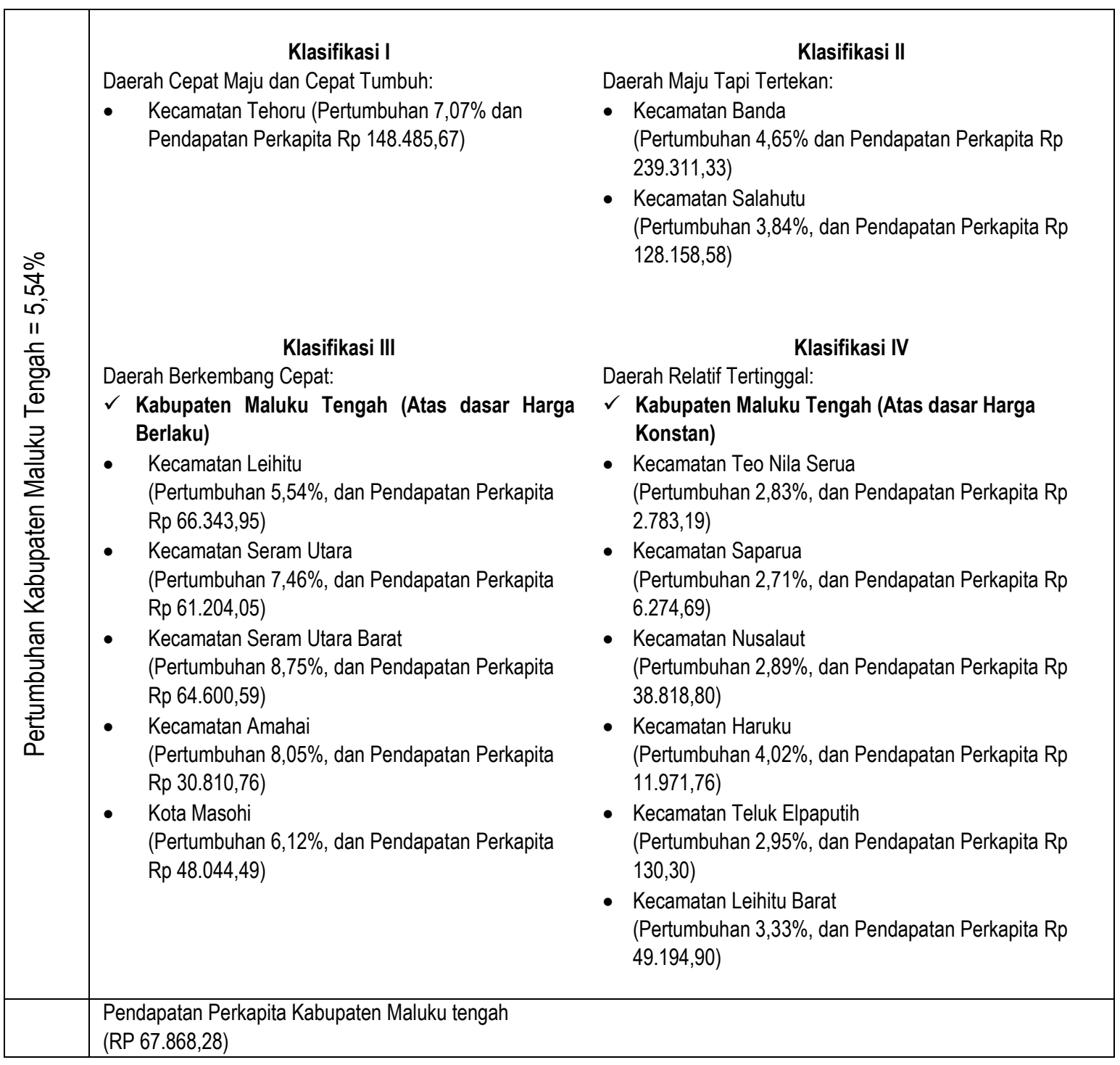

Gambar 7. Skema Tipologi Sektor Perikanan di Kabupaten Maluku Tengah Tahun 2006 - 2010 
Terdapat Perbedaan tipologi Klassen sektor perikanan di Kabupaten Maluku Tengah berdasarkan nilai PDRB atas dasar harga berlaku dan atas dasar harga konstan. Tarigan (2012) mengemukakan bahwa untuk mengetahui kenaikan pendapatan yang sebenarnya (riil), faktor inflasi harus dikeluarkan terlebih dahulu, dan pendapatan regional dengan faktor inflasi yang sudah ditiadakan merupakan pendapatan regional atas dasar harga konstan. Sehingga tipologi Klassen sektor perikanan di Kabupaten Maluku Tengah yang sebenarnya (riil) adalah bahwa sektor perikanan di Kabupaten Maluku Tengah saat ini berada pada kondisi relatif tertinggal dibandingkan dengan sektor perikanan di Provinsi Maluku (Gambar 7).

Untuk mengejar ketertinggalan pembangunan sektor perikanan di Kabupaten Maluku Tengah paling tidak terdapat dua indikator penting yang harus dilihat yakni, pertumbuhan sektor perikanan tiap tahun dan pendapatan perkapita penduduk di Kabupaten Maluku Tengah berdasarkan nilai PDRB sektor perikanan. Dari 11 kebijakan umum yang dapat dilakukan untuk meningkatkan pendapatan masyarakat yang secara umum, berarti meningkatkan perekonomian daerah (Tarigan, 2012), kebijakan yang dapat diterapkan khusus untuk sektor perikanan di Kabupaten Maluku Tengah adalah:

1. Produk sektor perikanan yang digunakan hanya untuk memenuhi kebutuhan lokal sebaiknya diusahakan agar dapatdiekspor, misalnya dengan peningkatan mutu, perbaikan jalur pemasaran, atau penyediaan volume dalam jumlah ekonomis untuk dipasarkan ke luar daerah.

2. Harus diusahakan prasarana dan sarana perhubungan yang baik dan lancar.

3. Perlu diusahakan masuknya dana investasi dari pemerintah ataupun swasta.

4. Masyarakat didorong untuk mengkonsumsi produk lokal dan industri didorong untuk lebih banyak memakai komponen lokal.

5. Penentuan tingkat pajak yang baik (memperhatikan berbagai aspek).

6. Penentuan komoditas perikanan yang diperkirakan dapattumbuh cepat di Kabupaten Maluku Tengah.

7. Langkah untuk memperbaiki kualitas sumber daya manusia perlu digalakan (aspek keahlian/keterampilan dan aspek moral/mental).

8. Mengontrol jumlah pertumbuhan penduduk di Kabupaten Maluku Tengah.

Kebijakan ini harus diprioritaskan pada enam kecamatan yang sektor perikanannya tergolong relatif tertinggal di Kabupaten Maluku Tengah, yakni Kecamatan Teon Nila Serua, Kecamatan Saparua, Kecamatan Nusalaut, Kecamatan Haruku, Kecamatan Teluk Elpaputih, dan Kecamatan Leihitu Barat. Sedangkan 5 kecamatan/kota lainnya, yakni Kecamatan Leihitu, Kecamatan Seram Utara, Kecamatan Seram Utara Barat, Kecamatan Amahai, dan Kota Masohi yang memiliki pertumbuhan sektor perikanan yang baik (tergolong dalam daerah berkembang cepat), namun memiliki tingkat pendapatan perkapita dari sektor perikanan yang lebih rendah masih membutuhkan beberapa kebijakan di atas. Hal serupa ditemui juga di Kecamatan Banda dan Kecamatan Salahutu yang tergolong daerah dengan sektor perikanan maju tetapi tertekan.

Salah satu kecamatan di Kabupaten Maluku Tengah yang sektor perikanannya tergolong cepat maju dan cepat tumbuh adalah Kecamatan Tehoru. Dengan pertumbuhan sektor perikanan diantara 5,56\% hingga 14,96\% dan pendapatan perkapita dari sektor perikanan sebesar Rp 132.554,41 hingga Rp 173.595,58 menempatkan kecamatan ini sebagai satu-satunya wilayah yang memiliki pertumbuhan dan pendapatan perkapita melebihi angka pertumbuhan dan pendapatan perkapita yang dimiliki Kabupaten Maluku Tengah secara agregat (Gambar 8). 


\section{SIMPULAN}

Kontribusi sektor perikanan sebesar $6,20 \%$ per tahun atas dasar harga berlaku dan 5,48\% pertahun atas dasar harga konstan menempatkan sektor perikanan pada urutan/peringkat kelima dan keenam dalam pembentukan PDRB di Kabupaten Maluku Tengah dibandingkan dengan 9 sektor lainnya.Sumbangan sektor perikanan dalam pembentukan PDRB tergolong rendah, sehingga perlu adanya pengembangan usaha-usaha dalam sektor perikanan baik perikanan taangkap dan budidaya perikanan.

Di tingkat wilayah Provinsi Maluku, sektor perikanan Kabupaten Maluku Tengah bukan merupakan sektor basis (non basis), dengan perkembangan nilai LQ yang menurun pada tahun terakhir analisis (tahun 2010). Terdapat 7 (tujuh) kecamatan yang merupakan basis sektor perikanan di Kabupaten Maluku Tengah meliputi: Kecamatan Banda, Tehoru, Salahutu, Leihitu, Seram Utara, Seram Utara Barat, dan Leihitu Barat.Kecamatan yang bukan merupakan basis sektor perlu didorong pertumbuhan komoditas perikanan pada pasar lokal dan internasional.

Sektor perikanan di Kabupaten Maluku Tengah sedang bertumbuh, namun berada pada kondisi relatif tertinggal, dengan pertumbuhan dan pendapatan perkapita sektor yang kecil dibandingkan dengan sektor perikanan di Provinsi Maluku. Kecamatan yang sektor perikanannya tergolong relatif tertinggal harus diprioritaskan pengembangan produk sektor perikanan dengan demikian diharapkan dapat membantu meningkatkan pertumbuhan sektor perikanan.

\section{REFERENSI}

Badan Pusat Statistik Maluku Tengah (BPS Maluku Tengah). (2010). Maluku Tengah dalam angka 2010. Masohi: BPS.

Badan Pusat Statistik. (2010). Maluku dalam angka 2010. Maluku: BPS.

Dinas Kelautan dan Perikanan Kabupaten Maluku Tengah. (2012). Profil Peluang Usaha dan Investasi Kelautan dan Perikanan Kabupaten Maluku Tengah. Masohi: Dinas Kelautan dan Perikanan Kabupaten Maluku.

Sutiardi, E. (2001). Skripsi Fakultas Perikanan dan Ilmu Kelautan. Bogor:IPB.

Tarigan, R. (2012). Ekonomi Regional Teori dan Aplikasi, Cetakan keempat. Jakarta: PT. Bumi Aksara. 